\title{
EUCALYPTUS LOGS DRYING AT HIGH TEMPERATURES ${ }^{1}$
}

\author{
Aylson Costa Oliveira ${ }^{2 *}$, Bárbara Luísa Corradi Pereira², Angélica de Cássia Oliveira Carneiro ${ }^{3}$, Lucas de \\ Freitas Fialho ${ }^{4}$, Clarissa Gusmão Figueiró ${ }^{4}$, Benedito Rocha Vital ${ }^{3}$ and Mateus Alves de Magalhães ${ }^{4}$
}

\footnotetext{
${ }^{1}$ Received on 07.06.2016 accepted for publication on 11.11 .2016

${ }^{2}$ Universidade Federal de Mato Grosso, Departamento de Engenharia Florestal, Universidade Federal de Mato Grosso, Cuiabá, Mato Grosso, Brasil. E-mail: <aylsoncosta@gmail.com> and < babicorradi@gmail.com>.

${ }^{3}$ Universidade Federal de Viçosa, Departamento de Engenharia Florestal, Universidade Federal de Viçosa, Viçosa, Minas Gerais, Brasil.E-mail: <cassiacarneiro1@gmail.com>and < benedito.vital@gmail.com>.

${ }^{4}$ Universidade Federal de Viçosa, Programa de Pós-Graduação em Ciência Florestal, Viçosa, Minas Gerais, Brasil. E-mail: <1.freitasfialho@gmail.com>, <clarissagfigueiro@gmail.com>and <mateusmagalhaes91@gmail.com>.

*Corresponding author.
}

\begin{abstract}
The objective of this work was to evaluate the drying speed of Eucalyptus urophylla logs in high temperatures and the influence of the presence or absence of bark and also the diameter of the log in the drying rate. Eucalyptus $\operatorname{logs} 60 \mathrm{~cm}$ long were divided into three diameter classes: $8-12 \mathrm{~cm} ; 12,1-16 \mathrm{~cm}$ and 16,1-20 cm. The logs were dried in a heater with forced air circulation, in the presence or absence of bark in five temperatures: $50,75,100,125$ and $150^{\circ} \mathrm{C}$. The mass and the initial moisture were determined from each log and the water loss was kept up with periodic weightings, closing the drying process when the $\log$ reached $20 \%$ moisture. The drying rate of the logs was calculated using the ratio between the total loss of moisture and the time in hours in order to reach the established moisture. It was concluded that the increase in temperature promotes the raise of the drying ratio, as being higher for smaller logs in relation to bigger ones and in addition to this, the bark effect was not significant in the drying of eucalyptus logs above $100^{\circ} \mathrm{C}$. It was also concluded that the best conditions for the operation of artificial dryers for Eucalyptus logs containing bark and separated in diameter classes would be at $125^{\circ} \mathrm{C}$.
\end{abstract}

Keywords: Drying rate; Moisture content; Artificial dryers.

\section{SECAGEM DA MADEIRA DE EUCALIPTO EM TORAS A ALTAS TEMPERATURAS}

RESUMO - O objetivo deste trabalho foi avaliar a velocidade de secagem de toras de Eucalyptus urophylla a altas temperaturas e a influência da presença ou ausência de casca e do diâmetro da madeira na taxa de secagem. Utilizaram-se toretes de Eucalyptus urophylla com $60 \mathrm{~cm}$ de comprimento, em três classes diamétricas: $8-12 \mathrm{~cm} ; 12,1-16 \mathrm{~cm}$ e 16,1-20 cm. Os toretes foram submetidos à secagem em estufa com circulação forçada de ar, na presença ou ausência de casca em cinco temperaturas: 50, 75, 100, 125 e 150 ${ }^{\circ} \mathrm{C}$. Determinouse a massa e a umidade inicial de cada torete e com pesagens periódicas acompanhou-se a perda de água, encerrando o processo de secagem quando os toretes de madeira atingiam a umidade de 20\%. A taxa de secagem foi calculada por meio da relação entre a perda total de umidade e o tempo total em horas para que as toras atingissem a umidade estabelecida. Conclui-se que o aumento da temperatura promove o aumento da taxa de secagem, sendo maior para as toras de menor diâmetro em relação às toras de maior diâmetro e na secagem das toras de eucalipto em temperaturas superiores a $100^{\circ} \mathrm{C}$, o efeito da casca não foi significativo. Conclui-se, também, que a melhor condição de operação de secadores artificiais para a madeira de eucalipto em tora seria em temperatura de $125^{\circ} \mathrm{C}$, com presença de casca e separadas em classes diamétricas.

Palavras-chave: Taxa de Secagem; Teor de Umidade; Secadores Artificiais. 


\section{INTRODUCTION}

The domestic charcoal producers, looking for production increase and better product quality, are adopting the best available and accessible technologies in the market, like large dimensions rectangular kilns with mechanized loading and unloading activities (Guimarães Neto et al., 2007; Arruda et al., 2011); carbonization control based on the kiln's internal temperature (Carvalho et al., 2012; Oliveira et al., 2013); and furnaces for the carbonization gases combustion that minimizes the polluting gases emissions to the environment (Cardoso et al., 2010; Costa, 2012).

According to Yang et al. (2007), during the wood's carbonization several carbon and hydrogen-rich gaseous compounds are generated, mainly $\mathrm{CO}, \mathrm{CO}_{2}, \mathrm{H}_{2}$ and $\mathrm{CH}_{4}$. At adequate temperature conditions, those gases could undergo chemical reaction at the presence of oxygen, with the emissions constituted of $\mathrm{CO}_{2}$ and water steam only and liberating energy in heat form (Cardoso et al., 2010). The temperature of the gases liberated to the environment through the chimney, after the combustion at the furnace interior, could reach temperatures from 200 to $500^{\circ} \mathrm{C}$ (Oliveira et al., 2013).

One way to take advantage of the heat generated by the furnaces in the productive process of the charcoal could be its redirection to the wood logs drying through industrial dryers. Since the outdoors wood drying, nowadays the main used method according to Zanuncio et al. (2013) demands a longer period of time for reducing the wood moisture to satisfactory levels for carbonization, between 30 and $40 \%$, also presenting great heterogeneity of the moisture scent related to the log dimensions and pile position.

In both drying methods, the wood characteristics plus the temperature, relative humidity and air circulation of the environment conditions influence the water outlet speed. However, in the outdoor drying the environment conditions will be the ones verified in the place where the wood is exposed, while in the artificial drying it's possible to change the environment by using fans for air circulation and renovation, heating systems to elevate the temperature and also the relative humidity control.

According to Galvão and Jankowsky (1985), higher temperatures favors the drying process of the wood, providing more energy for water evaporation and elevating the air potential to receive more water steam. Thus, the use of industrial dryers that employs as a heat source the combusted gases of carbonization allows the moisture homogenization in great volumes of wood, reduction of drying time and getting lower moisture scent than the usually verified levels at outdoor drying.

In the literature, several studies about some wood products can be found: particles, sheets and mainly lumber (Albuquerque, 2000; Jankowsky, 2000; Santini and Haselein, 2002). However, there are no studies about the application of this drying method in logs destined to carbonization.

Thus, the objective of this works was to evaluated the wood drying speed of Eucalyptus urophylla logs at higher temperatures, as a subsidy to future projects of industrial dryers. It was also aimed to evaluate the influence of the presence or absence of the bark and the wood diameter in the drying speed at different temperatures.

\section{MATERIAL AND METHODS}

The wood logs used in this study came from a 7-year old Eucalyptus urophylla plantation, cultivated with a $3 \times 2 \mathrm{~m}$ spacing, in the city of Viçosa/MG. This town has a 650 m average altitude, the weather-according to the Köppen classification - is a Cwb type, mesothermic, with a dry winter and rainy summer. The average annual precipitation is $1200 \mathrm{~mm}$ and the average annual temperature is $20,5^{\circ} \mathrm{C}$, with a minimum of $14,6^{\circ} \mathrm{C}$ and maximum of $26,3^{\circ} \mathrm{C}$ (Zucoloto et al., 2011).

\subsection{Sample preparation}

Seven eucalyptus trees, with diameter at breast height (DBH) of $18 \mathrm{~cm}$ and average height of $25 \mathrm{~m}$ were collected. Each tree was sectioned in logs with 1,3 m of length until the minimum diameter of $8 \mathrm{~cm}$.

The logs were taken to the Laboratório de Painéis e Energia da Madeira - LAPEM of the Universidade Federal de Viçosa - UFV, where the circumferences of the base and topo of the logs were determined for calculating the average diameter. Later, they were separated in three diameter classes.

The Class 1 was composed by the logs obtained in the superior part of the trees with 8 to $12 \mathrm{~cm}$ diameters; the Class 1 composed by logs obtained in the intermediated height region of the tree, with 12,1 to $16 \mathrm{~cm}$ diameters and the Class 3 by logs with 16,1 a $20 \mathrm{~cm}$, obtained closer to the tree bases. 
After the diameter separation, the $\log s$ were sectioned in $\operatorname{logs}$ of $60 \mathrm{~cm}$, with central circle of 10 $\mathrm{cm}$ of thickness being extracted from each log to determine the initial moisture from each log by the gravimetric method. Then, half of the logs of each diameter class keep their barks and the other half was manually peeled.

The logs were later put in elevated structure at $0,5 \mathrm{~m}$ of the ground in order to have a better air circulation between them in covered shed for natural drying until the average moisture level corresponds to $60 \%( \pm 10 \%)$. The initial mass of each log was determined, in which the initial moisture was estimated in accord to the verified moisture in the correspondent discos. Then, periodical weightins of the logs were made until the corresponding mass to the established moisture. At that moment, the natural drying was finished and the logs were put in plastic bags with decahydrated sodium tetraborate to reduce the loss of water and the attack of wood decomposing organisms until all the logs reached $60 \pm 10 \%$ moisture, for the later oven drying.

The moisture of $60 \%( \pm 10 \%)$ was established as the initial one for the logs at oven drying because the freshly harvested tree shows an elevated level of water filling its empty space, corresponding to free water, which output presents a low energetic expense, with an elevated water loss rate even with the field conditions drying. Lower than $60 \%$ moisture, even with free water in the wood log, the drying tax is reduced around five times, elevating the drying time.

With the initial drying happening in the field, the weight of the wood to be transported and the amount of water to be taken of the wood are reduced, lowering the energetic consume and the time of permanence in the artificial dryer.

\subsection{Wood oven drying}

After all the logs reach the $60 \%$ moisture level and put in plastic bags, a fraction of sawdust of all radial region (bark-marrow direction) was taken from each log using an electric drilling machine, according to the methodology described by Donato et al (2014). To estimate the initial moisture of each $\log$, the sawdust moisture was determined in a OHAUS MB35 Halogen determining scale with an halogen lamp.

Then, the initial mass of each log was determined and, before the oven drying was made, the far ends of the logs were waterproofed with metallic paint in order to minimize the loss of water in the longitudinal direction of the wood for the drying to happen preferably in the radial direction of the wood to evaluated the diameter effect and the bark presence or absence.

Later, the logs were taken to oven drying, evaluating the effect of the diameter, presence of absence of bark and different drying temperatures, $50,75,100,125$ and $150^{\circ} \mathrm{C}$, in the drying speed of the eucalyptus wood.

A Marconi lab oven drying with forced air circulation in the horizontal direction, with temperature control until $200^{\circ} \mathrm{C}$ and 480 liters of capacity was used. The internal structure of the oven drying is made of AISI430 stainless steel with a double chamber for air circulation and the external structure a 1020 steel sheet with an anticorrosive treatment, with the following internal dimensions: $800 \mathrm{~mm}$ width; $600 \mathrm{~mm}$ deep and $1000 \mathrm{~mm}$ height, with a 5 steel shelves support where the logs were disposed. The temperature sensor was a PT100 type.

To achieve the drying speed, the logs were individually weighted at regular time intervals that varied in accordance to the evaluated treatment, finishing the drying at the oven drying when the logs reached a mass corresponding to $20 \%( \pm 2 \%)$ of moisture. The wood moisture through time was calculated from the estimated wet mass and dry mass from each log.

From the average moisture levels of the logs over time and the real time needed for the logs achieve 20\% moisture, the making of the drying curves in terms of diametric class, bark presence or absence and drying temperature at the oven drying followed. Using the CurveExpert 1.4 software, models that could explain the moisture reduction over time or the drying curves, selecting the best among them based in the determination coefficient $\left(\mathrm{R}^{2}\right)$, standard residual error and residue distribution, could be defined.

Through the existing relation between the total loss of moisture and the total necessary time, in hours, for the logs to reach the final moisture closer to $20 \%$ after the oven drying, the reduced moisture per hour drying rate $\%$, in function of the treatments, could be calculated in accord to the Equation 1.

$$
\text { Drying rate }(\% / \text { hour })=\frac{\text { Ui }- \text { Uf }}{t} \times 100
$$


In which,

$\mathrm{Ui}=$ Initial wood $\log$ moisture (\%);

$\mathrm{Uf}=$ Final wood $\log$ moisture (\%);

$\mathrm{T}=$ Necessary time to reach $20 \%$ of moisture (hours).

\section{RESULTS}

The mathematic model that better describes the reduction in the moisture scent of the logs in the different treatments (bark presence or absence, log diameter and drying temperature, except for $150^{\circ} \mathrm{C}$, Classes 1 and 2) over time was an exponential model of two parameters:

$$
y=a * \exp (-b x)
$$

In which:

$\mathrm{y}=$ estimated moisture value for eucalyptus logs (\%)

$\mathrm{x}=$ drying time (days)

$\mathrm{a}, \mathrm{b}=$ model parameters

For the $150^{\circ} \mathrm{C}$ temperature with presence or absence of bark for logs with diameter varying between 8 and $12 \mathrm{~cm}$ (Class 1) and between 12,1 and $16 \mathrm{~cm}$ (Class 2), the model that was better suited to the moisture reduction values over time was a liner one with two parameters:

$$
y=a x+b
$$

In which:

$\mathrm{y}=$ estimated moisture value for eucalyptus logs $(\%)$

$\mathrm{x}=$ drying time (days)

$\mathrm{a}, \mathrm{b}=$ model parameters

Probably, the linear model for drying at $150^{\circ} \mathrm{C}$ for the 1 and 2 Classes is due to the higher water evaporation water and log drying speed because of the higher temperature.

The adjusted equations to the eucalyptus wood log average moisture scent estimate over time presented determination coefficients $\left(\mathrm{R}^{2}\right)$ higher than $99 \%$, thus showing that the model was satisfactory in modeling the wood log drying. The estimates of the parameters $a$ and $b$ for the drying curves in the different conditions for temperature, diameter and bark are presented in the Table 1.
In the figures 1 and 2 are presented the average estimated values of moisture in the eucalyptus logs over time, in the different temperatures of oven drying for each diametric class, in the presence and absence of bark.

In Table 2 are presented the drying rates, reduction of moisture scent per hour, for the eucalyptus logs, in the different temperatures of oven drying for each diametric class, in the presence and absence of bark.

It can be verified in the figures 1 and 2 that the $\log$ s with smaller diameter, of the Class 1 , show the lower drying times, except for the drying made at $50^{\circ} \mathrm{C}$. In average, for the Class 2 logs to reach $20 \%$ of moisture, the necessary time was $50 \%$ superior to the one verified to Class 1 . For the larger diameter logs of the Class 3 , the drying time was 2 and 3 times superior, respectively, that the ones of the Classes 1 and 2 .

The differences in the drying times (Figures 1 and 2) are caused by the verified differences between the diametric classes in the drying rates, that lower with the increase of the diameter of the logs (Table 2). In general, higher drying rates can be observed for the logs of Class 1, thus the lower drying times. For Class 2 , there was an average reduction of $40 \%$ in the drying rate, resulting in the average drying times, while the Class 3 logs showed the longer drying times because of the drying rates, in average $20 \%$ lower than Class 2 and $50 \%$ than Class 1 .

\section{DISCUSSION}

According to Vital et al. (1985), the log diameter is related to the distance to be traveled by the water inside the wood to the surface, where it will evaporate. Thus, the longest time of drying and the lower drying rate of the larger diameter logs in relation of the other classes, evidencing the effect of the wood dimension on the water outlet. So, it is verified that even with the drying happening in natural conditions, the diameter of the logs affects the speed of the water escape of the wood's interior, thus influencing the drying time, so it's recommended the separation of the logs in diametric classes before the oven drying for a better operation and better homogeneity of the moisture scent of the wood.

It can be seen that the eucalyptus logs drying period is reduced with the raise of the oven drying temperature, for the different diameters and in the 
Eucalyptus logs drying at high temperatures...

Table 1 - Parameters set of templates to moisture content reduce of the logs over time for Class 1, 2 and 3 at different temperatures and in bark presence and absence.

Tabela 1 - Parâmetros dos modelos ajustados para redução do teor de umidade das toras ao longo do tempo para as Classes 1, 2 e 3, nas diferentes temperaturas e na presença e ausência de casca.

\begin{tabular}{|c|c|c|c|c|c|}
\hline Diametric Class & Temperature & Bark & $a$ & $b$ & $\mathrm{R}^{2}$ \\
\hline \multirow{10}{*}{$\begin{array}{c}\text { Class } 1 \\
(\varnothing 8-12 \mathrm{~cm})\end{array}$} & \multirow{2}{*}{$50^{\circ} \mathrm{C}$} & Present & 71,75 & 0,07 & 0,9955 \\
\hline & & Absent & 65,462 & 0,059 & 0,9991 \\
\hline & \multirow{2}{*}{$75^{\circ} \mathrm{C}$} & Present & 58,253 & 0,325 & 0,9963 \\
\hline & & Absent & 55,576 & 0,355 & 0,9961 \\
\hline & \multirow{2}{*}{$100^{\circ} \mathrm{C}$} & Present & 55,258 & 0,666 & 0,9965 \\
\hline & & Absent & 57,502 & 0,87 & 0,9929 \\
\hline & \multirow{2}{*}{$125^{\circ} \mathrm{C}$} & Present & 51,932 & 1,931 & 0,9675 \\
\hline & & Absent & 50,879 & 1,889 & 0,9987 \\
\hline & \multirow{2}{*}{$150^{\circ} \mathrm{C}^{*}$} & Present & $-55,007$ & 44,666 & 0,9973 \\
\hline & & Absent & $-49,957$ & 47,071 & 0,9992 \\
\hline \multirow{10}{*}{$\begin{array}{c}\text { Class } 2(\varnothing 12,1 \\
-16 \mathrm{~cm})\end{array}$} & \multirow{2}{*}{$50^{\circ} \mathrm{C}$} & Present & 50,127 & 0,044 & 0,9958 \\
\hline & & Absent & 46,148 & 0,068 & 0,9889 \\
\hline & \multirow{2}{*}{$75^{\circ} \mathrm{C}$} & Present & 55,668 & 0,151 & 0,9951 \\
\hline & & Absent & 53,464 & 0,192 & 0,9949 \\
\hline & \multirow{2}{*}{$100^{\circ} \mathrm{C}$} & Present & 48,964 & 0,474 & 0,9940 \\
\hline & & Absent & 50,673 & 0,551 & 0,9908 \\
\hline & \multirow{2}{*}{$125^{\circ} \mathrm{C}$} & Present & 45,005 & 0,907 & 0,9774 \\
\hline & & Absent & 55,615 & 0,908 & $\overline{0,9871}$ \\
\hline & \multirow{2}{*}{$150^{\circ} \mathrm{C}^{*}$} & Present & $-40,144$ & 53,597 & 0,9865 \\
\hline & & Absent & $-37,963$ & 48,947 & 0,9942 \\
\hline \multirow{10}{*}{$\begin{array}{c}\text { Class } 3(\varnothing 16,1 \\
-20 \mathrm{~cm})\end{array}$} & \multirow{2}{*}{$50^{\circ} \mathrm{C}$} & Present & 54,693 & 0,040 & 0,9963 \\
\hline & & Absent & 50,128 & 0,059 & 0,9959 \\
\hline & \multirow{2}{*}{$75^{\circ} \mathrm{C}$} & Present & 79,600 & 0,086 & 0,9978 \\
\hline & & Absent & 78,455 & 0,095 & $\overline{0,9981}$ \\
\hline & \multirow{2}{*}{$100^{\circ} \mathrm{C}$} & Present & 68,930 & 0,420 & 0,9957 \\
\hline & & Absent & 59,546 & 0,420 & 0,9984 \\
\hline & \multirow{2}{*}{$125^{\circ} \mathrm{C}$} & Present & 67,466 & 0,674 & 0,9894 \\
\hline & & Absent & 74,060 & 0,739 & $\overline{0,9903}$ \\
\hline & \multirow{2}{*}{$150^{\circ} \mathrm{C}$} & Present & 71,451 & 0,618 & 0,9823 \\
\hline & & Absent & 69,161 & 0,607 & 0,9922 \\
\hline
\end{tabular}

*Linear model

presence or absence of bark. Thus, the distances between the drying curves and the different drying periods verified in the Figures 1 and 2 are a result of the differences that exist between the drying rates in each temperature (Table 2).

The lower average drying rate, $0,08 \% /$ hour, happened at the $50^{\circ} \mathrm{C}$ temperature; when the log drying was made at $75^{\circ} \mathrm{C}$, the drying rate was elevated at around 4 times, presenting a value equal to $0,30 \%$ /hour, while that for $100^{\circ} \mathrm{C}$, which the average drying rate value was $0,82 \%$ /hour, the rate was 2,7 times higher than the one verified at the $75^{\circ} \mathrm{C}$ temperature and 10 times higher than at $50^{\circ} \mathrm{C}$. For the $125^{\circ} \mathrm{C}$ temperature, it can be observed that the 2 times increase in the drying rate which average value was $1,68 \%$ /hour; there was no alteration in the average value of the drying rate observed at the $150^{\circ} \mathrm{C}$ temperature in relation to the $125^{\circ} \mathrm{C}$ one. Thus, the 5 time increase in the drying temperature made a 20 time increase in the drying rate of the wood $\log$. As verified in this work, Santini and Haselein (2002) observed a higher drying rate for Pinus sawed wood in more elevated temperatures, in this case $110^{\circ} \mathrm{C}$ in relation to $50^{\circ} \mathrm{C}$. 

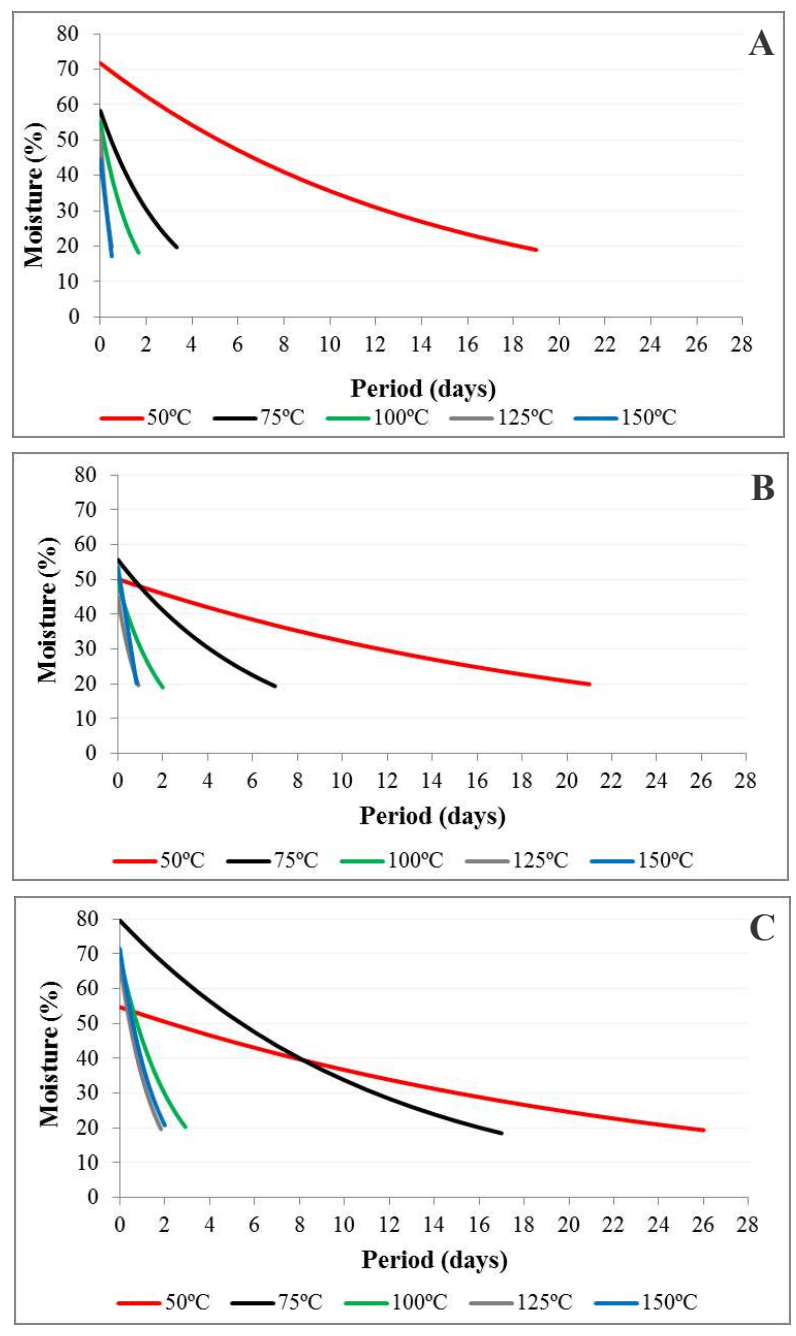

Figure 1 - Average estimated values of moisture from the Eucalyptus logs with bark, in drying temperature function. (A) Class $1(\varnothing 8-12 \mathrm{~cm}) ;($ B) Class 2 (Ø 12,1-16 cm); (C) Class 3 (Ø 16,1-20 cm).

Figura 1 - Valores médios estimados de umidade das toras de eucalipto com casca em função da temperatura de secagem. (A) Classe 1 (Ø 8-12 cm); (B) Classe 2 (Ø 12,1-16 cm); (C) Classe 3 (Ø 16,1-20 cm).

Raad (1997), when evaluating the Eucalyptus spp. wood drying between 75 to $225^{\circ} \mathrm{C}$, has verified a $30 \%$ decrease in the the drying period for each $25^{\circ} \mathrm{C}$ temperature increase until $150^{\circ} \mathrm{C}$, higher than this temperature there were no alterations in the drying curve and in the total drying time. This work verified that until the temperature of $125^{\circ} \mathrm{C}$, variable reductions of 2 to 3 times in the drying period and, from $125^{\circ} \mathrm{C}$, the increase of the drying temperature to $150^{\circ} \mathrm{C}$ promoted
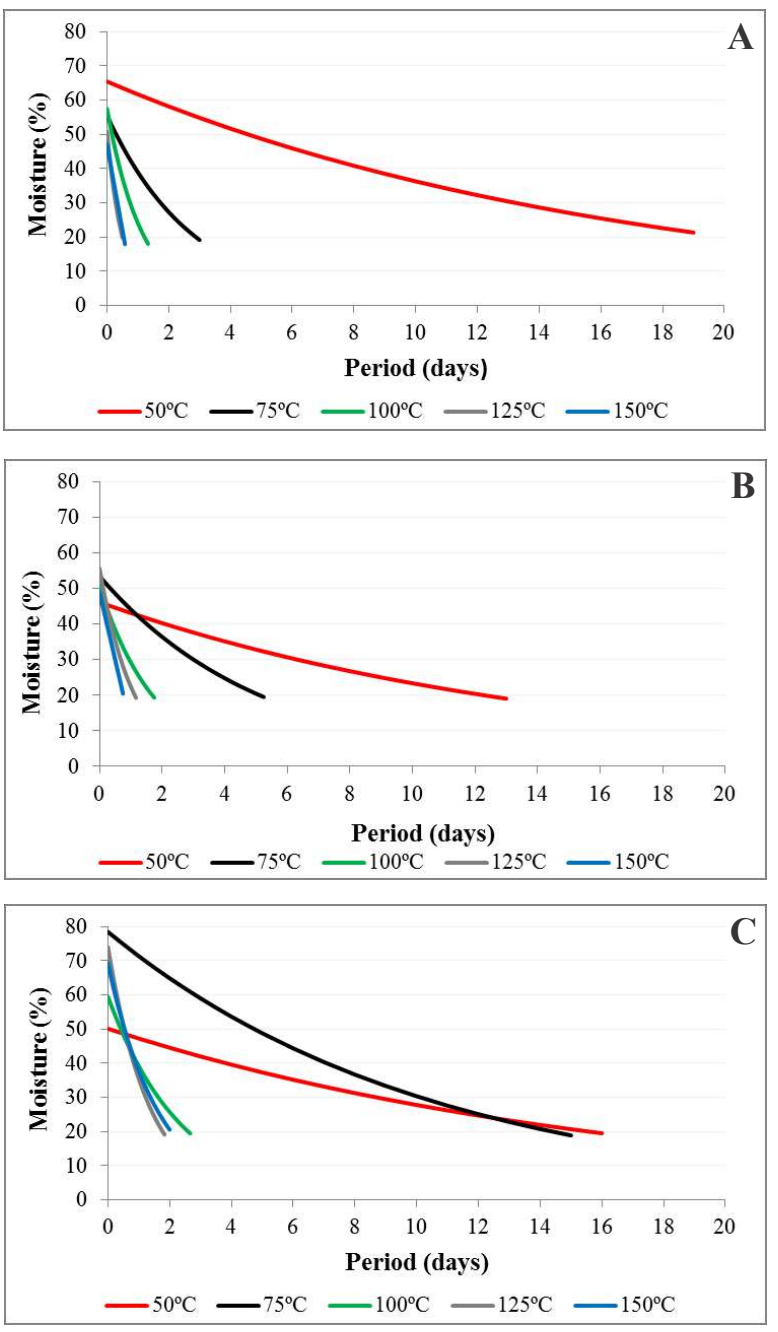

Figure 2 - Average estimated values of moisture from the Eucalyptus logs without bark, in drying temperature function. (A) Class 1 (Ø 8-12 cm); (B) Class 2 (Ø 12,1-16 cm); (C) Class 3 (Ø 16,1-20 cm).

Figura 2 - Valores médios estimados de umidade das toras de eucalipto sem casca em função da temperatura de secagem. (A) Classe 1 (Ø 8-12 cm); (B) Classe 2 (Ø 12,1-16 cm); (C) Classe 3 (Ø 16,1-20 cm).

a reduction of $10 \%$ in the period of time, or no alteration, as verified for the Class 1 logs.

The lower drying time at high temperatures is due to the increase of heating supply rate to the wood, resulting in a increase of the speed in the migration speed of the internal moisture to the surface, elevating the drying speed (Santos et al, 2010; Coelho, 2013). Another reason for the higher drying efficiency is the 
Table 2 - Average drying rate values, \%/hour, Eucalyptus logs depending on the drying temperature, diameter class, and bark presence or absence.

Tabela 2 - Valores médios da taxa de secagem, \%/hora, das toras de eucalipto em função da temperatura de secagem, classe diamétrica e presença ou ausência de casca.

\begin{tabular}{|c|c|c|c|c|c|c|}
\hline \multirow[t]{2}{*}{ Diametric Class } & \multirow[t]{2}{*}{ Bark } & \multicolumn{5}{|c|}{ Drying rate (\%/hour) } \\
\hline & & $50^{\circ} \mathrm{C}$ & $75^{\circ} \mathrm{C}$ & $100^{\circ} \mathrm{C}$ & $125^{\circ} \mathrm{C}$ & $150^{\circ} \mathrm{C}$ \\
\hline \multirow{2}{*}{ Class 1(Ø 8-12 cm) } & Present & 0,12 & 0,48 & 0,93 & 2,68 & 2,29 \\
\hline & Absent & 0,09 & 0,51 & 1,31 & 2,59 & 2,43 \\
\hline \multirow{2}{*}{ Class $2(\varnothing 12,1-16 \mathrm{~cm})$} & Present & 0,06 & 0,22 & 0,64 & 1,15 & 1,67 \\
\hline & Absent & 0,09 & 0,27 & 0,75 & 1,30 & 1,58 \\
\hline \multirow{2}{*}{ Class $3(\varnothing 16,1-20 \mathrm{~cm})$} & Present & 0,06 & 0,15 & 0,70 & 1,09 & 1,06 \\
\hline & Absent & 0,08 & 0,17 & 0,63 & 1,25 & 1,01 \\
\hline
\end{tabular}

higher drying speed of the wood's surface, elevating the moisture gradient between the surface and interior, also elevating the air capacity to receive a higher amount of water steam.

Several studies evaluating the natural drying of eucalyptus logs report that the minimum drying period is around 60 days for lesser diameter logs reach a $30 \%$ average moisture (Rezende et al., 2010; Pinheiro, 2013). Thus, the use of oven dryings with elevated temperatures is an option for reducing the wood log drying time and obtaining lower moisture scents, because for reaching a $20 \%$ moisture were necessary an average period of 20 days of drying at $50^{\circ} \mathrm{C} ; 8$ days at $75^{\circ} \mathrm{C} ; 2$ days for $100^{\circ} \mathrm{C}$ and 1 day to $150^{\circ} \mathrm{C}$, with longer times for the larger diameters logs being verified.

In artificial dryers projects that aim to use the carbonization combusted gases as heat source, it is necessary the mix of the gases with the ambient air for fitting the fluid temperature to the more secure drying condition, since according to Oliveira et al., (2013), the liberated gases from the furnace reach temperatures that varies from 200 to $500^{\circ} \mathrm{C}$. Thus, aiming to the wood log drying, the more elevated temperatures would be the more indicated ones to the dryer operation because of the necessity of lower temperature reduction of the furnace gases and the higher drying speed resulting in a lower occupation time of the drying chamber, allowing the wood drying for several carbonization cycles.

However, because of how the differences among the drying time and rates between the $125^{\circ}$ and $150^{\circ} \mathrm{C}$ temperatures (Table 2) were not expressive, it is recommended that the wood log drying operation in metallic industrial dryers to be made at $125^{\circ} \mathrm{C}$, aiming for less damage to the structure of the dryer and fire risk, mainly when the wood presents a low moisture scent.
Generally, higher drying rates can be verified for the barkless logs, reflecting at lower drying times at the oven drying. For the $50^{\circ} \mathrm{C}$ temperature, the average difference between the rates was $25 \%$; at 75 and $100^{\circ} \mathrm{C}$, there was a reduction in this difference, which varied between 15 and $20 \%$, with a significant difference in these temperatures for the drying periods until the stablished moisture scent being noticed. For the temperatures higher than $100^{\circ} \mathrm{C}$, difference of less than $10 \%$ between the drying rates for bark and barkless logs were observed, resulting in drying times equal or closer, differences of 2 to 4 hours, for drying conducted at 125 and $150^{\circ} \mathrm{C}$ in the different diametric classes.

Vital et al. (1985); Rezende et al. (2010) and Pinheiro (2013) evaluating the natural drying of eucalyptus wood $\log$ s noticed that the bark presence influences in the drying period, becoming less effective with the moisture scent reduction. For the drying at superior than $100^{\circ} \mathrm{C}$ temperatures, like the evaluation at this work, there was no significant effect of the bark presence on the drying time of eucalyptus logs, regardless of the diameter. Thus, the artificial dryers for wood log should operate at the 100 to $150^{\circ} \mathrm{C}$ temperature rate for the debarking to be unnecessary, because it elevates the costs and activities involved in the production of wood made for carbonization.

\section{CONCLUSION}

The wood log drying at oven dryings at higher temperatures promoted the moisture reduction to values next to $20 \%$ for all the diametric classes, with the presence or absence of bark, in periods of less than 30 days.

The rise in the temperature promoted the increase of the drying rate and thus reducing the drying time, 
without alteration from $125^{\circ} \mathrm{C}$. The bark presence Eucalyptus urophylla wood log was insignificant in the drying at temperatures higher than $100^{\circ} \mathrm{C}$, so the debarking is not recommended.

The drying rate of the smaller diameter logs were superior to the verified rates of the larger ones at the same temperature conditions, resulting in differences in the drying period, with the recommendation for the logs to be separated in diametric classes before the oven drying.

The best condition for operation artificial dryers for eucalyptus wood logs would be with the presence of the bark, separated in diametric classes and at $125^{\circ} \mathrm{C}$.

\section{ACKNOWLEDGEMENTS}

The authors would like to thank the Scientific and Technological Development National Council (CNPq); the Foundation of Support Research of the Minas Gerais State (FAPEMIG); the Secretary of State and Science, Technology and Superior Education (SECTES); the Forest Excellence Hub, the Forest Development Steelworks Association (ASIFLOR), Charcoal Thematic Group-G6.

\section{REFERENCES}

Albuquerque CEC. Desenvolvimento de um sistema de pré-secagem de partículas de Pinus e de Eucalipto para produção de chapas de madeira aglomerada. Floresta e Ambiente, 2000;7(1):104-20.

Arruda TPM, Pimenta AS, Vital BR, Lucia RMD, Acosta FC. Avaliação de duas rotinas de carbonização em fornos retangulares. Revista Árvore. 2011;35(4):949-55.

Cardoso MT, Damásio RAP, Carneiro ACO, Jacovine LAG, Vital BR, Barcellos DC. Construção de um sistema de queima de gases da carbonização para redução da emissão de poluentes. Cerne. 2010;16:115-24.

Carvalho SR, Borges VL, Mulina BHO, Oliveira RLM, Figueira Júnior EA, Pessoa Filho JS. Instrumentação térmica aplicada ao processo de produção de carvão vegetal em fornos de alvenaria. Revista Árvore. 2012;36(4):787-96.

Coelho LDN. Modelagem e simulação da secagem Revista Árvore. 2017;41(2):e410207 de partículas sólidas de biomassa em temperaturas típicas de combustão [monografia]. Brasília-DF: Universidade de Brasília; 2013.

Costa JMFN. Temperatura final de carbonização e queima dos gases na redução de metano, como base à geração de créditos de carbono [dissertação]. Viçosa-MG: Universidade Federal de Viçosa; 2012.

Donato DB, Castro RVO, Carneiro ACO, Carvalho AMLM, Pereira BLC, Oliveira AC, et al.

Determinação da umidade da madeira em tora por diferentes métodos. 2014. Pesquisa Florestal Brasileira. 2014;34(80):449-53.

Galvão APM, Jankowsky IP. Secagem racional da madeira. São Paulo: Nobel; 1985.

Guimarães Neto RM, Pimenta AS, Silva ML, Soares NS, Vital BR, Silva JC. Avaliação econômica e financeira de projetos de fornos dos tipos container industrial e retangular de 40 estéreos. 2007. Revista Árvore, 2007;31(4):709-15.

Jankowsky IP. Melhorando a eficiência dos secadores para madeira serrada. 2000. 14p. (Circular Técnica IPEF, 191)

Oliveira AC, Carneiro ACO, Pereira BLC, Vital BR, Carvalho AMML, Trugilho PF, et al. Otimização da produção do carvão vegetal por meio do controle de temperaturas de carbonização. Revista Árvore. 2013;37(3):557-66.

Pinheiro MA. Influência das dimensões da madeira na secagem e nas propriedades do carvão vegetal [dissertação]. Viçosa-MG: Universidade Federal de Viçosa; 2013.

Rezende RN, Lima JT, Paula LER, Faria ALR. Secagem ao ar livre de toras de Eucalyptus grandis em Lavras, MG. Cerne. 2010;16:41-7.

Raad TJ. Modelagem do processo de secagem do Eucalyptus spp a altas temperaturas [dissertação]. Belo Horizonte: Universidade Federal de Minas Gerais; 1997.

Santini EJ, Haselein CR. Efeito da temperatura e velocidade do ar sobre a taxa de secagem da madeira de Pinus elliotti Engelm. Ciência Florestal. 2002;12(2):99-106.

Santos CT, Bonomo RF, Chaves MA, Fontan RCI, Silf 
Bonomo P. Cinética e modelagem da secagem de carambola (Averrhoa carambola L.) em secador de bandeja. Acta Scientiarum Technology. 2010;32(3):309-13.

Vital BR, Della Lucia RM, Valente OF. Estimativa do teor de umidade de lenha para carvão em função do tempo de secagem. Revista Árvore. 1985;9:10-27.

Yang H, Yan R, Chen H, Lee DH, Zheng C.

Characteristics of hemicellulose, cellulose and lignin pyrolysis. Fuel. 2007;86:1781-8.

Zanuncio AJV, Monteiro TC, Lima JT, Andrade HB, Carvalho AG. Drying biomass for energy use of Eucalyptus urophylla and Corymbia citriodora Logs. BioResources. 2013;8(4):5159-68.

Zucoloto M, Costa MG, Carvalho LM, Santos D, Siqueira DL. Estimativa da produção de sementes de porta-enxertos cítricos por meio da massa de frutos. Revista Ceres, 2011;58(1):126-8. 